\title{
The Orwellian Reality of Counter-Terrorism Measures Under The ECHR
}

\author{
Sam Thyroff-Koh1* \\ https://doi.org/10.21827/GroJIL.8.1.90-109
}

\section{Keywords}

NATIONAL SECURITY; HUMAN RIGHTS; PROPORTIONALITY; SAFEGUARDS

\begin{abstract}
This paper seeks to analyze the impact of terrorism on the enjoyment of civil liberties guaranteed under the European Convention on Human Rights (ECHR). The paper profoundly assesses case law from the European Court of Human Rights (ECtHR) in order to assess how the Court manages to guarantee that rights are still respected and upheld, even when weighed against the most severe circumstances, namely terrorism. In doing so, the counter-terrorism legal system of one of the most controversial parties to the ECHR, the United Kingdom, is assessed to identify issues which arise when combating terrorism. Surveillance and stop-and-search are archetypical anti-terrorism measures that are limited through the ECtHR in order to not excessively infringe upon human rights, in accordance with Lloyd's notion of imposing sufficient safeguards if new measures are enacted. Although the ECtHR can be considered an essential guarantor for human rights through its judicial dialogues and influences on domestic courts and governments, the issue of refoulment in torture cases must be readdressed in upcoming case-law. Moreover, grave privacy infringements are permitted to a terrifying extent, and the longer the ECtHR takes to take a solid stance against States abusing the aim of national security, the more severe it will naturally become, due to society's incremental progression towards a digital life. Ultimately, terrorism tests democratic governments in a unique way, as imposing draconian measures would be an easy way to ensure safety. Nonetheless, fighting with one hand behind one's back is necessary to uphold the status of a rights-respecting democracy. Only time will tell whether the ECtHR will evolve to give proactive verdicts to ensure human rights prior to their breach.
\end{abstract}

\section{Introduction}

'War is peace. Freedom is slavery. Ignorance is strength' - George Orwell

Throughout decades, terrorism has been rapidly shifting away from its archetype due to modern terrorists becoming more extreme and less discriminate by employing new technologies and strategies. As a consequence of the exponential increase in the severity of terror attacks following 9/11, abundant legal debate has been stimulated regarding States' approaches to combating this never-ending threat. Since 9/11, academics distinguish between modern and traditional terrorism, claiming that modern terrorists are more ruthless, indiscriminate, do not negotiate or compromise and have a religious rather than

* LLM at University of Groningen (2020); LLB, University of Groningen (2019); Newcastle University Erasmus (2018). All errors are his own.

1 George Orwell, 1984 (Secker \& Warburg 1949) 4. 
secular motive for their attacks. ${ }^{2}$ Due to this distinction, governments claim that there is a need for a vast increase in counter-terrorism measures, which cause several human rights infringements. When making new legislation, it is essential that States do not undermine or infringe upon human rights to a disproportionate extent, as - predominantly Western States aspire to maintain their status of being legitimate, human rights respecting States. Thus, a dichotomy between national security and the maintenance of adequate human rights standards exists and must be considered carefully. As Benjamin Franklin once said, 'Those who would give up essential Liberty to purchase a little temporary Safety, deserve neither Liberty nor Safety'. ${ }^{3}$ Moreover, the threat of terrorism is peculiar, as the total number of deaths that result from acts of terrorism is relatively low when compared to other homicide tolls or merely road traffic accidents. ${ }^{4}$ Nonetheless, the implications of terrorism and its indiscriminate attacks on citizens are extremely dangerous to society. Thus, governments tend to impose strict counter-terrorism measures in order to protect the safety of their citizens. It ought to be essential that governments do not over-react via draconian measures and disproportionately limit fundamental freedoms, which is why the European Court of Human Rights is an essential safeguard for legitimate, democratic States. Accordingly, the ECtHR serves to protect citizens from the potential danger of Member States' encroachment on individual liberties, thus working as a Winston Smith to the 'thought police'.

This paper will aim to answer the question of whether the ECtHR treats terrorism equally to other criminal affairs or manages crimes with a terrorist element under a separate legal sphere. Next, through analysing the interplay between the ECtHR and the State parties, the question of how the Court has applied the proportionality test in order to strike a balance between security and other rights will be assessed. Ultimately, this will result in an answer to the final question: how the war against terrorism has affected the enjoyment of fundamental rights of individuals, and if the ECHR guarantees adequate protection of human rights.

This dissertation will firstly lay out the European framework for countering terrorism and analyze the need for a special system for counter-terrorism legislation. Secondly, the proportionality test will be scrutinized by explaining the extent to which particular fundamental freedoms of the ECHR can be restricted in the name of national security due to threats of terrorism in Western States. As to the methodology, ECtHR caselaw on the infringement of Articles 3, 8 and 15 ECHR will be analyzed deductively, through assessing how the ECtHR applies the proportionality and necessity requirements and whether these are adequate safeguards. Subsequently, whether the derogation clause under Article 15 ECHR undermines and weakens the strength of the aforementioned freedoms will be discussed. Lastly, through engagement with ECtHR case law, the ECtHR's stance on the draconian measures of surveillance and stop-and-search imposed

2 Martha Crenshaw, "New" versus "Old" Terrorism: Is today's "new" terrorism qualitatively different from pre-September 11 "old" terrorism?' (2003) 10(1) Palestine-Israel Journal of Politics, Economic and Culture 5-7; Bruce Hoffman, Inside Terrorism (Colombia University Press 2006) 242-246.

3 Liberty fund, 'Benjamin Franklin on the trade off between essential liberty and temporary safety (1775)' (Online Library of Liberty, 25 February 2020) <oll.libertyfund.org/quotes/484> accessed 15 August 2020.

4 Institute for Health Metrics and Evaluation, 'Share of deaths by cause, World' (Our World in Data, 2017) <ourworldindata.org/grapher/share-of-deaths-by-cause-2016> accessed 10 August 2020; Anthony Cordesman, 'The Comparative Threat from Terrorism Compared to Drug Poisoning, Suicide, Traffic Accidents, and Murder: 1999-2016' (Centre for Strategic \& International Studies, 2018) <csis.org/analysis/comparative-threat-terrorism-compared-drug-poisoning-suicide-trafficaccidents-and-murder $>$ accessed 10 August 2020. 
by the UK will be evaluated, thereby culminating with an answer to the question of how terrorism affects the enjoyment of human rights.

The research will be limited to parties to the ECHR, mainly the UK, as these countries are affected by similar forms of terrorism and are therefore comparable. The UK has been implementing numerous counter-terrorism measures since 'The Troubles' in Northern Ireland and has continued to do so from 9/11 onwards. Consequently, numerous landmark ECtHR cases have been devised through the UK's judicial dialogue with the ECtHR. Furthermore, human rights are a concern to all citizens in Europe, whether EU citizens or third country nationals, thus the demarcation lines between when to restrict freedoms in the name of national security and when not has implications on society as a whole.

\section{European Counter Terrorism Framework}

Defining an action as terrorism triggers special repressive competences. Hence, the term ought to be as narrow as possible..$^{5}$ Terrorism is generally defined as a fear-inspiring method of violence for political or religious motives, whereby the general populace, rather than the direct victims, is the main target. ${ }^{6}$ The scope of counter-terrorism measures is determined by acts that constitute terrorism. An unclear universal definition of terrorism leads to ambiguity in practice, because defining the scope of terrorism offences is at the discretion of every State. ${ }^{7}$ An example of such juxtaposing views is the perception of Osama bin Laden, who was initially seen as a freedom fighter by the USA during the resistance of the Soviet occupation of Afghanistan, afterwards a terrorist once he had become unfavorable to the USA. ${ }^{8}$

Stigmatizing an act or a group in light of terrorism has the ability to delegitimize them, due to the negative connotations of terrorism implying a moral and social judgment. The lack of a definition allows for pejoratives surrounding alleged terrorists, thus a battle for legitimacy between government and terrorist groups emerges. Ultimately, this war can open itself to opportunism, attributable to the uncertainty revolving around the term. ${ }^{9}$ Therefore, it is relevant to assess whether a harmonized definition is achievable in order to reap the benefits of better cooperation and communication in the global fight against terrorism. Moreover, States' judicial enforcement would benefit greatly, due to the sense of rapprochement and harmonization that would be enabled through a unified definition. Moreover, the lack of a definition leads to a quagmire for legal certainty and nonretroactivity, both principles being essential to a democratic State under the rule of law. ${ }^{10}$ The issues surrounding nulla poena sine lege would be solved, through a universal definition enabling the foreseeable application of anti-terrorism laws by separating a legal meaning from a political concept. Moreover, for the sake of fairness, it is not plausible to allow the definition of terrorism to be at the discretion of States' unilateral interpretations. ${ }^{11}$ The nonexistent, universal, legally codified definition of terrorism leads to the possibility of

Max Hill, The Terrorism Acts In 2017 (APS Group 2018) 131.

Alex Schmid and Albert Jongman, Political Terrorism (Transaction Publishers 1987) 28.

7 Christian Walter, 'Terrorism', Max Planck Encyclopaedia of Public International Law (2011) <opil.ouplaw.com/view/10.1093/law:epil/9780199231690/law-9780199231690-

e999?prd=EPIL > accessed 3 June 2019.

8 Sami Zeidan, 'Desperately Seeking Definition: The International Community's Quest for Identifying the Specter of Terrorism' (2004) 36(3) Cornell International Law Journal 491-492.

9 Ben Saul, Defining Terrorism in International Law (Oxford University Press 2006) 3.

10 ibid 46.

11 Ben Saul, 'Defining “Terrorism” to Protect Human Rights' in D Staines (ed), Interrogating the War on Terror: Interdisciplinary Perspective (Cambridge Scholars Publishing 2007) 190-210. 
misusing the term through politicizing it to encompass non-terrorist acts, thus undermining the rights of citizens in order to curb such activities.

To solve the issue of a non-harmonized definition of terrorism, the Parliamentary Assembly of the Council of Europe, which oversees the European Court on Human Rights, construed a broad definition of terrorism stating that it is:

any offence committed by individuals or groups resorting to violence or threatening to use violence against a country, its institutions, its population in general or specific individuals which, being motivated by separatist aspirations, extremist ideological conceptions, fanaticism or irrational and subjective factors, is intended to create a climate of terror among official authorities, certain individuals or groups in society, or the general public. ${ }^{12}$

Moreover, Article 1 of the European Council Common Position on the application of specific measures to combat terrorism ${ }^{13}$ claims that a harmonized definition operates as a benchmark for cooperation between domestic governments, ${ }^{14}$ yet follows the UN's approach of banning an extensive list of illegal conduct. ${ }^{15}$

The approach taken by the ECtHR is rather distant, as it is predominantly left for national governments to ensure security. Nonetheless, the Council of Europe seeks to harmonize terrorism prevention methods in order to improve efficiency in dealing with the global threat of terrorism. The European Arrest Warrant is a prime archetype of European unity, involving Member States working in harmony to prosecute terrorists throughout their territories. Article 1 of the Council of Europe Convention on the Prevention of Terrorism prohibits a multitude of offences annexed thereto which have been established through international treaties. ${ }^{16}$ The Convention aims to strengthen Member States in preventing terrorism through criminalizing particular acts that may fall within the ambit of terrorist offences, for example public provocation and recruitment. ${ }^{17}$ Besides this, national prevention policies and existing extradition arrangements are to be reinforced. ${ }^{18}$ The Convention has been ratified by 40 Member States, ${ }^{19}$ and becomes applicable when there is an international dimension to a relevant situation, thereby assisting extraditions and the European fight against terrorism. ${ }^{20}$ The Convention utilizes the concept of commission of an act for the purpose of committing a terrorist offence, thereby ordinary acts can be unlawful if commenced for the purpose of a terrorist act. Examples of this are Article 5, concerning public provocation to commit a terrorist offence, and Article 7, providing instruction for the purpose of carrying out terrorist acts. ${ }^{21}$ Nevertheless, merely relying on existing sectoral conventions for a definition of terrorism leaves holes through

12 Council of Europe, 'European democracies facing up to terrorism' Parliamentary Assembly Recommendation 1426 (1999) para 5.

13 Council Common Position of 27 December 2001 on the application of specific measures to combat terrorism [2001] OJ 2 344/93.

14 Replacing Council Framework Decision 2002/475/JHA of 13 June 2002 on Combating Terrorism [2002] L 164/3 and amending Council Decision 2005/671/JHA of 20 September 2005 on the exchange of information and cooperation concerning terrorist offences [2005] L 253/22 art 1.

15 ibid art 3.

16 Council of Europe Convention on the Prevention of Terrorism (adopted 16 May 2005, entered into force 1 June 2007) CETS No. 196.

17 ibid art 5.

18 ibid art 17.

19 ibid.

20 Adrian Hunt, 'The Council of Europe Convention on the Prevention of Terrorism' (2006) 12(4) European Public Law 605.

21 ibid 610. 
which acts which have not been banned explicitly, yet have a terrorist intention, can fall. The reason for this is to ensure that the Convention does not conflict with other treaties, nor Member States' own definitions. In this way, the acquis of existing legislation is maintained. Yet, simultaneously, the Convention provides legal bases for potential terrorist actions..$^{22}$

That being said, States are required through United Nations Security Council (UNSC) Resolution 1373, pursuant to 9/11, to utilize national legislation in order to combat terrorism globally. ${ }^{23}$ For this reason, Article 1 of the United Kingdom's Terrorism Act $2000,{ }^{24}$ on the interpretation of terrorism, was adjusted by the Terrorism Act 2006 to include threats or uses of terrorism against international governmental organizations. ${ }^{25}$ Despite the Resolution obliging States to take action, without a concrete and global definition of terrorism, States still have leeway to legislate on terrorism, which can allow them to manufacture dangerously vague definitions thereof. Thereby, activities that are considered to be normal such as paintballing, ${ }^{26}$ or owning plant fertilizer, ${ }^{27}$ can lead to convictions for the offences of training for terrorism or owning terrorist materials. On the other hand, the semantics of terrorism have changed through time as States and organizations have attempted to construct a fitting definition to distinguish terrorism from ordinary criminal violence. Due to the struggle of coining a value-neutral international definition, the European Convention on Human Rights opts to use a United Nations-esque sectoral approach, thereby banning an exhaustive list of actus rei ${ }^{28}$ which makes a concise definition on terrorism redundant. ${ }^{29}$ Therefore, the ECtHR, as well as the European Union, seem to be content with prohibiting several commissions of offences, which avoids the need to subjectively condemn a group. ${ }^{30}$ The next section shall analyze how the ECtHR treats terrorism and answer the question of whether the ECtHR considers terrorism to fall within the ambit of ordinary crime or under a special system.

\section{The Necessity of Anti-terrorism Laws}

Lloyd argues that a 'crime model' is the optimal way of fighting terrorism, as States should opt to treat terrorists as closely to ordinary criminals as possible in order to avoid the alienation of particular minorities through singling them out as prime perpetrators of terrorist offences. ${ }^{31}$ In so far as possible, the State ought not to use a special system to combat terrorism, as this shows weakness in the ordinary criminal procedure in dealing

22 ibid 10.

23 UNSC Res 1373 (28 September 2001) UN Doc S/Res/1373.

24 Terrorism Act 2000, s1.

25 Terrorism Act 2006, s 34.

26 Press Association, 'Bricklayer convicted of trying to join Isis after training at paintball centre' (The Guardian, 15 December 2016) <theguardian.com/uk-news/2016/dec/15/bricklayer-convicted-of-tryingto-join-isis-after-training-at-paintball-centre> accessed 3 June 2019.

27 National Counter Terrorism Security Office, 'Secure your fertilizer' (GovUK, 24 November 2014) < <gov.uk/government/publications/secure-your-fertiliser/secure-your-fertiliser> accessed 15 August 2020. Terrorism: US Procedural Aspects (Martinus Nijhoff Publishers 1988) 15-16.

29 Terry Davis, Human rights and the fight against terrorism (Council of Europe Publishing 2005) 13-15.

30 ibid.

31 Lloyd Berwick, Inquiry into terrorism legislation (Cm 3420, 1996) para 3. 
with government threats. ${ }^{32}$ Criminal law has the quintessential purpose of preventing forbidden conduct, declaring certain conduct illegal and expressing social condemnation towards crimes. This has a significant relevance to terrorism, due to the symbolic value of criminalizing terrorist acts in order for governments to gain popular support through ensuring the safety of their citizens. Creating anti-terrorism laws in times of terrorist threats is an easy win for a government when it comes to obtaining voters, as it shows that the government is protecting its people. Through criminalizing terrorism, the message that terrorism is an abhorrent crime is demonstrated to the public and helps shape a communal public repugnance towards terrorist groups and their aspirations. ${ }^{33}$ As a consequence of treating terrorists and criminals alike, they become condemned whilst the government's authority becomes legitimized. Democratic values, such as public trials, result in justice being seen to be done, as well as trust in the State's ability to protect its population. Checks and balances help to guarantee that the guilty are convicted, whilst maintaining a high standard of human rights, as abandoning rights in the pursuit of safety would finally lead to the loss of both. ${ }^{34}$ Therefore, some risks are worthwhile for the enjoyment of liberty. ${ }^{35}$

The dyad of the Islam-West has endured more killings than any other pairs of civilizations across the globe. ${ }^{36}$ Therefore, there is an assumption that a trade-off between civil liberties and the risk of terrorist attacks exists. This leads to the interpretation that liberal democracies must create a trade-off between civil liberties and national security. On the other hand, in a democratic society, citizens grant the State competences and legitimacy only to the extent that order and peace are guaranteed. Therefore, excessive force by the State may encourage citizens to retaliate in opposition and more 'rebels' to emerge. ${ }^{37}$ Moreover, when a State begins to evolve from merely infringing democratic participation to physical harm in the sense of torture and summary executions, a justification for rebel groups to resort to violence is created as human security rights have been violated. ${ }^{38}$ Consequently, implementing a human rights based approach to combating terrorism does not leave a country more prone to threats; it strengthens the rule of law whilst hindering the recruitment of further alienated individuals to terrorist groups. ${ }^{39}$ Due to this, States must avoid using draconian measures and rather attempt to fairly prosecute and try accused perpetrators to ensure that the Lloyd principle ${ }^{40}$ keeping counter-terrorism law as similar to ordinary criminal law as possible, is respected. ${ }^{41}$

32 In contrast, the 'war model' would consider the war against terrorism to be an armed conflict, thus potentially making terrorists combatants falling under the Geneva Conventions. As a result, States would be permitted to employ military necessity until submission of the enemy, leading to the potential of collateral damage. Alongside the dangers of civilian life, human rights can be easily infringed due to the State being able to make an easy claim for a state of national emergency.

33 Diaz-Paniagua, Negotiating terrorism: The negotiation dynamics of four UN counter-terrorism treaties (University of New York 2008) 41.

34 Todd Landman, 'Imminence and Proportionality: The US and UK Responses to Global Terrorism' (2007) 38(1) Californian Western International Journal 106.

35 Clive Walker, The Ashgate Research Companion to Political Violence: Human Rights and Counterterrorism in the UK (Ashgate Publishing Limited 2012)10.

36 Eric Neumayer and Thomas Plümper, 'International terrorism and the clash of civilizations' (2009) 39(4) British Journal of Political Science 728-734.

37 Landman (n 30) 85.

38 Rhonda Callaway and Julie Harrelson-Stephens, 'Toward a Theory of Terrorism: Human Security as a Determinant of Terrorism' (2006) 29(8) Studies in Conflict \& Terrorism 778.

39 Landman (n 30) 78.

40 Berwick (n 27).

41 Clive Walker, The Ashgate Research Companion to Political Violence: Human Rights and Counterterrorism in the UK (Ashgate Publishing Limited 2012) 10. 
Nevertheless, in reality, some special powers of arrest are needed, as the grave consequences of terrorism are a risk neither the public nor police can bear to take. ${ }^{42}$ In addition, different States and their inhabitants value safety to altering extents. In particular, countries living in the presence of greater terrorist threats permit human rights violations more easily as necessary to combat terrorism more effectively. Dogmatically, the judiciary contravenes the executive or legislative decision makers to preserve constitutionally protected rights. However, in times of emergency, courts often sidestep issues in order to avoid conflict with the governmental branches, thereby capitulating legitimacy. ${ }^{43}$ An example of this was during 'The Troubles', where numerous coerced confessions were used in court. Due to the state of emergency, the courts deemed the government to be more suitable at risk assessment, even though this is debatable as the judiciary is not influenced by the populace. ${ }^{44}$ As a consequence thereof, the ECtHR becomes an important body of judicial oversight, which can step in in cases where domestic courts fail to protect human rights.

Since the 1998 Human Rights Act, ${ }^{45}$ UK courts have been granted the unprecedented ability to remark on, yet not void, provisions violating said Act. Nonetheless, courts do not operate within an isolated vacuum, as they too are subject to the fear instilled through terrorist threats and thus are not entirely objective when reflecting and judging upon the legislature's decision making. During times of national emergency, the trias politica suffers as a consequence of the threat at hand. For instance, British courts gave abundant, perhaps even excessive, leeway to counter-terrorism policies and competences against Northern Irish rebels, even allowing law enforcement officers to 'shoot to kill.' ${ }^{46}$ Notably, Lord Bingham asserted that since the entry into force of the Human Rights Act, courts have the function of upholding the rule of law in human rights cases, thereby possessing the prerogative to independently interpret and apply the law, as this is a quintessential characteristic of the modern democratic State. ${ }^{47}$

Terrorism entails a uniquely dangerous threat to sovereign States, especially democratic ones, due to the State no longer having a monopoly over the use of force. ${ }^{48}$ This struggle over the legitimate use of force has resulted in numerous countries turning to the legal doctrine of proportionality, which is essential when creating, as well as implementing, counter-terrorism measures. Accordingly, the infringement of human rights ought to be no greater than what is necessary to prevent terrorist attacks. Therefore, domestic European courts strive to function as guardians of the rule of law and to find the intricate balance between security and human rights. Terrorist threats lead to primary and secondary victims. However, civilians should not be victims of courts allowing the overrestriction of their rights. ${ }^{49}$ Terrorist offences differ from ordinary criminal activities, in the sense that they are punishable from their mere commencement and through the fact that they are politically motivated. In other words, acts which are preparatory to a terrorist crime are already punishable, which is not the case in ordinary criminal law. For example, ordinary English criminal law ${ }^{50}$ states that an act has to be 'more than merely preparatory'

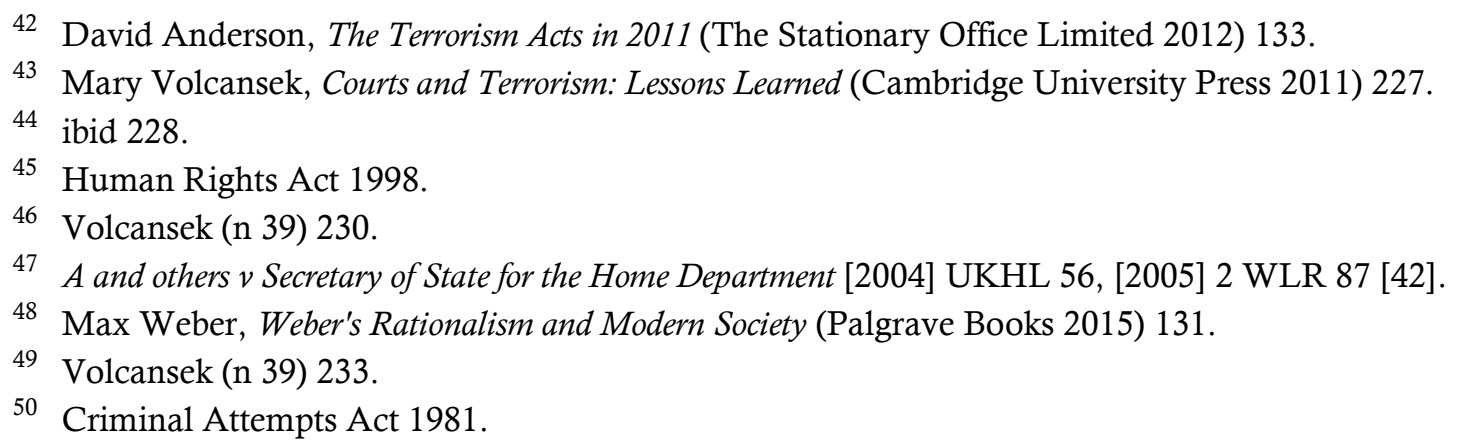


in order to constitute an offence..$^{51}$ The reasoning behind this is the harm principle. As there is a threat to a person's security when a crime is attempted, from a utilitarian standpoint an individual who attempts to commit a crime is dangerous, and thus must be punished as a deterrent to themselves and others. ${ }^{52}$ However, careful consideration must be given to the maintenance of human rights when seeking to convict terrorists, as measures that are too far-reaching can be counterproductive by creating more alienation within society and thus an increase in the number of terrorist recruits. Modern terrorists utilize anxiety in order to stimulate politicians to over-react, thus causing the side-effect of discrimination and alienation of particular groups. Modern terrorists are deemed to have a divine motivation for their acts. ${ }^{53}$ However, Al-Qaeda pursued a war against American imperialism, as stated after 9/11. Al-Qaeda used this line of thought to their advantage, through appealing to alienated Muslims who felt discriminated in Western Countries, ${ }^{54}$ and through politicians who took discriminate, targeted measures, further creating a vicious circle of alienation. ${ }^{55}$ An example of a measure overstepping human rights boundaries is that of stop-and-search, which was used in a blanket manner disproportionately against ethnic minorities, thus alienating segments of the population in the UK. This will be analyzed further below.

\section{Proportionality as a Safeguard for Human Rights}

When balancing rights against one another, the methodology used by the ECtHR consists of firstly determining whether the infringement of liberty falls under the scope of the rights protected through the ECHR. Next, the ECtHR applies the proportionality test, which is intrinsic to the necessity test and is composed of three steps. The first step is the legality test, meaning the Court determines if the interference is prescribed by law and in pursuit of a legitimate aim. Consequently, the Court assesses whether the interference is necessary in a democratic society and whether the measure is suitable to achieve the legitimate aim or if there is a less burdensome alternative. Lastly, proportionality is assessed sensu stricto. ${ }^{56}$ The Court accomplishes the final step through balancing the impact of the right infringed with the foreseeable benefit of the measure. ${ }^{57}$ One can consider the principle to be an optimization mechanism, whereby values are compared and ranked against one another. For example, when the intrusion of a person's liberty is low and the benefit to society is large then the individual loses their right and vice versa. ${ }^{58}$ The way the proportionality test is employed seems to weigh the interests of the applicant with those of the government pertaining to the interest of society, ultimately basing the decision on utilitarianism in the sense of what is best for society. Therefore, the proportionality test can be criticized as it is au contraire to the anti-utilitarian nature of rights, as they are intended to protect individuals

51 ibid s1(1).

52 Clarkson, Clarkson and Keating Criminal Law: Text and Materials (Sweet \& Maxwell 2010) 473.

53 Crenshaw (n 2) 245.

54 The Guardian, 'Full text: bin Laden's "letter to America"' (The Guardian, 24 November 2002) $<$ theguardian.com/world/2002/nov/24/theobserver> accessed 15 August 2020.

55 Paddy Hillyard, Suspect Community: People's Experience of the Prevention of Terrorism (Pluto Press in association with NCCL/Liberty 1993) 173.

56 Jan Jans 'Proportionality Revisited' (2000) 27(3) Legal Issues of Economic Integration 239, 241.

57 George Letsas, The Scope and Balancing of Rights: The Role of the European Court of Human Rights in Determining the Scope of Human Rights (Cambridge University Press 2014) 42.

58 Robert Alexy, 'Constitutional rights, balancing and rationality' (2003) 16(2) Ratio Juris 131, 133. 
without regard to society in general..$^{59}$ If all rights were balanced based on utilitarianism then most would be restricted. For example, a person expressing something mildly offensive would always be restricted as the utility created through restricting the right would be greater. ${ }^{60}$ Thus, the restriction of rights should not be subject to utilitarian style cost-benefit analyses, but rather assessed on a case-by-case basis.

In the context of counterterrorism, the ECtHR's approach can be criticized, as it allows national governments to prioritize national security over individual rights. This undermines ECHR rights, which should be protected. On the other hand, safety can equally be considered a human right, providing it is also an obligation of domestic governments. The ECtHR serves as a forum for judicial dialogue between Council of Europe Member States in combating terrorism, and through analyzing this dialogue the leeway granted through the proportionality and necessity tests can be assessed. The next part of this paper shall analyze how the ECtHR applies the proportionality test to safeguard fundamental freedoms, particularly Article 8 ECHR: the right to private life.

\section{A. Proportionality in Relation to Private Life}

Through juxtaposing the ECtHR's approach towards Article 8 ECHR infringements in ordinary criminal proceedings with its method regarding infringements with terrorist elements, one can analyze the effect that terrorism has on several aspects of the right to private life. It is important to note that Article $8 \mathrm{ECHR}$ is a relative fundamental freedom, meaning that it can be restricted, as opposed to an absolute right such as Article 3 ECHR on torture, which cannot. Further, in this paper, the difference between the ECtHR's rulings on absolute rights in a terrorist context will be delineated to depict how some rights can be relinquished with ease.

Article 8 ECHR has the salient purpose of protecting individuals against arbitrary interferences into their family or private life. The ECtHR has interpreted the right as simultaneously a negative obligation ${ }^{61}$ and a positive one. ${ }^{62}$ Member States must also guarantee that this freedom is upheld between private parties. ${ }^{63}$ The text of the Article declares that everyone has the right to respect for private and family life, alongside their home and correspondence. ${ }^{64}$ The interpretation of 'home' was further clarified in Niemietz $v$ Germany ${ }^{65}$ where the French term 'domicile' was utilized in order to broaden the scope of private life to include a person's business premises and work vicinity. Indeed, the right is not absolute and can therefore be restricted if there is a legitimate aim, ${ }^{66}$ which justifies an interference by a public authority when 'necessary in a democratic society in the interests of national security and public safety. ${ }^{67}$ The exception in practice firstly makes use of a necessity analysis followed by a proportionality test, in order to determine whether an infringement of private life is permissible. This approach will be used in the example of

59 Stavros Tsakyrakis 'Proportionality: an assault on human rights?' (2009) 7(3) International Journal of Constitutional Law 468, 471-472.

60 Letsas (n 51) 49.

61 Kroon and Others $v$ the Netherlands App no 18535/91 (ECHR, 27 October 1994) para 31.

62 Von Hannover v Germany (2005) 40 EHRR 1.

63 Evans v the UK App no 6339/05 (ECHR, 10 April 2007) para 75.

64 Convention for the Protection of Human Rights and Fundamental Freedoms (European Convention on Human Rights, as amended) (ECHR) art 8(1).

65 Niemietz v Germany App no 13710/88 (ECHR, 16 December 1992) paras 29-31.

66 ECHR (n 58) art 8(2).

67 Right to respect for private and family life or the economic well-being of the country, for the prevention of disorder or crime, for the protection of health or morals, or for the protection of the rights and freedoms of others. 
the ECtHR's stance on stop-and-search. The Court has identified that the grounds for interference must be sufficient as well as pertinent, ${ }^{68}$ and the necessity test requires that the restriction must be established convincingly. ${ }^{69}$

Although the ECtHR is quite rigorous in its consideration of exceptions to Article $8,{ }^{70}$ the balance between the reason for the right being infringed and the right itself remains a quintessential question regarding the margin of appreciation granted to Member States. Member States are responsible for assessing whether a circumstance which would give rise to the infringement of a fundamental freedom exists due to the fact that their government has leeway to determine a legitimate interest. Hence, in the context of terrorism, it is the Member State who determines when a national emergency exists or when public safety is in jeopardy. The reason for the ECtHR allowing a margin of discretion is that the domestic government is in a better position to determine the security situation of its territory than a court in Strasbourg. ${ }^{71}$ Despite the leeway given to Member States, the ECtHR claims to be the ultimate arbiter, after consulting legislation and domestic institutions and having regard to the case as a whole, to assess whether the aim and necessity of the infringement are compatible with the ECHR. ${ }^{72}$

The ECtHR considers the fight against terrorism to be exceptional, thus granting leeway to Member States when they pursue legitimate and proportionate aims to prevent terrorism. ${ }^{73}$ Nevertheless, the Court still takes the protection of individuals into account when determining the compatibility of an infringement with Article $8 \mathrm{ECHR}^{74}$ This is achieved by ensuring that counter-terrorism laws contain adequate safeguards to prevent abuse. ${ }^{75}$ Another example of the Court applying the proportionality test to weigh national security considerations against individual rights is the case of Sabanchiyeva and Others $v$ Russia. ${ }^{76}$ The case revolved around the Russian authorities prohibiting a funeral of Chechen rebels in the name of national security, under their anti-terror legislation. The ECtHR judgment stated that a fair balance between the forestallment of disturbance, which could have potentially arisen during the funeral proceedings, alongside the feelings of the victims of terrorism and the applicant's right to pay respect through a burial had not been struck. Despite the Court's appreciation of the State's position in regards to the threat of terrorism, counter-terrorism law has enabled the automatic refusal of burials for terrorists and has failed to take a case-by-case approach to the individual circumstances of the departed.

On the other hand, in a recent judgment, ${ }^{77}$ the applicant was prevented from paying her respects to her deceased father. The ECtHR agreed with the local authorities' decision because the convicted terrorist applicant had not renounced her ETA membership and there was no possibility to organize a timely escort. Therefore, the Court held that the

68 The Observer Ltd and Others, Guardian Newspapers Ltd and Others $v$ The United Kingdom App no 13585/88 (ECHR, 12 July 1990) para 72.

69 Autronic AGv Switzerland App no 12726/87 (ECHR, 22 May 1990) para 61; Weber v Switzerland App no 11034/84 (ECHR, 2 May 1990) para 47; Barthold v Germany App no 8734/79 (ECHR, 25 March 1985) para 58.

70 Klass and Others v Germany App no 5029/71 (ECHR, 6 September 1978 ) para 42.

71 Steven Greer, The Margin of Appreciation: Interpretation and Discretion Under the European Convention on Human Rights (Council of Europe Publishing 2000) 8.

72 Handyside $v$ The United Kingdom App no 5493/72 (ECHR, 7 December 1976) para 48; The Sunday Times $v$ The United Kingdom App no 6538/74 (ECHR, 26 April 1979) paras 50, 59.

73 Erdem v Germany App no 38321/97 (ECHR, 9 December 1999) paras 60, 66-69.

74 Murray v The United Kingdom App no 18731/91 (ECHR, 27 August 1991) para 91.

75 Khamidov v Russia App no 72118/01 (ECHR, 23 October 2006) para 143.

76 Sabanchiyeva and Others $v$ Russia App no 38450/05 (ECHR, 6 June 2013).

77 Guimon v France App no 48798/14 (ECHR, 11 April 2019). 
French authorities had not overstepped their margin of appreciation. This demonstrates that the ECtHR truly does take a case-by-case approach and applies the proportionality test to render justice in each individual case, taking into account the particular circumstances.

In Nada v Switzerland, ${ }^{78}$ the Court further reiterated its statement that domestic authorities must take the particular circumstances of the case into account. The Court held that there had been a violation of Article 8 ECHR due to the non-removal of the applicant's name from the Swiss Taliban Ordinance, in which he was listed due to his prior placement on the UN Security Council Sanctions Committee's list of persons suspected of association with al-Qaeda and the Taliban. The applicant had not been found guilty of any terrorist offence, and thus his right to an effective remedy and a private life had been infringed, as he was restricted from seeing family and receiving medical attention. Despite UN Security Council Resolution 1267, the ECtHR deemed that the Swiss authorities must nevertheless take the individual's situation into account, emphasizing the importance of the proportionality assessment being based on a case-by-case approach.

The following section aims to analyze the ECtHR's use of the proportionality safeguard to alter the UK's stop-and-search measure, thus preventing the infringement of human rights as well as further alienation of affected individuals.

\section{B. Proportionality of the UK's Stop-and-Search Measure}

According to Pantazis and Pemberton, ${ }^{79}$ building upon Hillyard's 'suspect community' theory in Northern Ireland, ${ }^{80}$ the stop and search competence was used disproportionately against ethnic minorities. The wide discretion granted to police officers required no reasonable ground for suspicion, thus leading to the alienation of minority groups, predominately Muslims. On the other hand, Greer disagreed with the aforementioned hypothesis ${ }^{81}$ claiming that it relied upon interpretive, empirical and logical errors due to the treatment of Muslims as one homogenous group and the consequent failure to address the alienation of Muslims not associated with terrorism. Greer deemed stop-and-search to be a flawed counter-terrorism measure due to its arbitrariness and lack of prosecutions, despite being utilized extensively. ${ }^{82}$ In day to day affairs, stop-and-search was introduced to enable police officers to determine whether an individual may be guilty of a crime without having to make an arrest, thus being convenient for innocent civilians. In scenarios where stop-and-search is utilized, the legitimate aim thereof is the protection of national security. Therefore, the domestic courts must ensure that the aim is proportionate to the burden the individual incurs due to the consequent infringement of their right to a private life. The ECtHR steps in when the domestic courts have failed to protect individuals' human rights and an application to the ECtHR is made after the individual has exhausted all domestic remedies. The legal bases for stop-and-search fall under numerous pieces of

78 Nada v Switzerland App no 10593/08 (ECHR, 12 September 2012).

79 Christina Pantazis and Simon Pemberton, 'From the "Old" to the "New" Suspect Community: Examining the Impacts of Recent UK Counter-Terrorist Legislation' (2009) 49(5) The British Journal of Criminology 646-655.

80 Paddy Hillyard, Suspect Community: People's Experience of the Prevention of Terrorism (Pluto Press in association with NCCL/Liberty 1993) 173-176.

81 Steven Greer, 'Anti-Terrorist Laws and The United Kingdom's: A Reply to Pantazis and Pemberton' (2010) 50(5) British Journal of Criminology 1171, 1171-1175.

82 Only $1.4 \%$ of those stopped and searched were arrested - see National statistics, 'Police powers and procedures, England and Wales, year ending 31 March 2018' (Gov.UK, 2018) <gov.uk/government/statistics/police-powers-and-procedures-england-and-wales-year-ending-31march-2018> accessed 3 June 2019. 
legislation such as Section 6(1) Police and Criminal Evidence Act (PACE) ${ }^{83}$ and the Aviation Security Act 1982, Section 27(2), ${ }^{84}$ which requires a reasonable ground for suspicion in order for the measure to be utilized fairly and in a discriminatory manner. Although searches carried out with the aim of preventing terrorism fall under Schedule 7 to the 2000 Terrorism Act, Sections 44 and $47^{85}$ have no reasonable suspicion requirement and are thus exposed to the opportunity of misuse. In contrast, the goal behind PACE was to construct an equilibrium between the rights and freedoms of the individual and the competences of the police. In practice, the extensive use of stop-and-search proved that this competence did not merely deter terrorism, but also infringed upon numerous individuals' rights to protest and assemble. ${ }^{86}$ Consequently, Gillan and Quinton brought a case to the ECtHR ${ }^{87}$ after having used their domestic remedies to claim an infringement of Article 8 ECHR, which the Court granted. The two individuals, who had been attending a protest at an arms fair in London, were stopped and searched and subsequently had some possessions seized. The Court reasoned that the competences held by police officers were not subject to sufficient legal safeguards to prevent abuse, nor were they adequately restricted to certain scenarios, ${ }^{88}$ resulting in an adaptation of the UK's Stop and Search legislation by the Home Secretary, making the measure lawful only when there is a reasonable suspicion of an individual being a terrorist. ${ }^{89}$

The ECtHR has since further strengthened the significance of the right to private life, even in the context of counter-terrorism legislation. In a recent judgment, ${ }^{90}$ the Court found an infringement of Article $8 \mathrm{ECHR}$ as a consequence of the arbitrary detention of people for a duration of up to nine hours. Moreover, they were compelled to respond to questions without access to a lawyer or being formally arrested. The case was in 2011 and revolved around an applicant being stopped and questioned at an airport whilst trying to visit her convicted terrorist husband, which has since led to an amendment of the UK counter-terrorism legislation. As of 2014, frontier officials must arrest a person in order to interrogate them for a duration exceeding one hour and grant prior access to a lawyer, as well as releasing the suspect after no more than six hours. ${ }^{91}$ The ECtHR held that the legislation at time of questioning was too broad, lacked safeguards and did not take the newly amended UK legislation into account. Presumably, the newly adopted legislation has been altered to contain sufficient safeguards. However, the ECtHR does not ignore the fact that terrorism is a serious hazard to national security, as manifested in Sher. Following Sher, the search of a person's domicile during custody was not held to be a violation of Article $8 \mathrm{ECHR},{ }^{92}$ as the urgency of the fight against terrorism calls for a broadly phrased search warrant. There must, however, be safeguards to ensure that the warrants are not arbitrarily granted and are permitted by a judge. Ultimately, the ECtHR seems to be satisfied if Member States stay within the limits of their marginal discretion when restricting Article $8 \mathrm{ECHR}$. The leeway granted when national security is at stake is

83 Police and Criminal Evidence Act $1984 \mathrm{sec} 6(1)$.

84 Aviation Security Act $1982 \mathrm{sec} 27(2)$.

85 Terrorism Act $2000 \mathrm{sec} 44,47$.

86 Louise Smith, 'Human Rights and Powers of Stop and Search' (About Human Rights, 29 August 2017) $<$ abouthumanrights.co.uk/human-rights-powers-stop-search.html> accessed 3 June 2019.

87 Gillan and Quinton $v$ The United Kingdom App no 4158/05 (ECHR, 12 January 2010) para 10.

88 ibid.

89 ibid para 86.

90 Beghal v The United Kingdom App no 4755/16 (ECHR, 28 February 2019).

91 ibid.

92 Sher and Others $v$ The United Kingdom App no 5201/11 (ECHR, 20 October 2015). 
broader, due to the domestic authorities being better suited to determine a security hazard. The following section addresses the proportionality of surveillance measures used in the UK to combat terrorism.

\section{Proportionality of Surveillance when Countering Terrorism}

The national security justification is highly relevant to counter-terrorism operations, as secret surveillance is often used and regarded as an interference with Article 8 ECHR. Despite this, in the ECtHR's jurisprudence, it has been allowed in situations where surveillance was strictly necessary in order to safeguard democratic institutions. ${ }^{93}$ The margin of discretion is limited to the extent to which the court must be convinced that the surveillance in question was subject to sufficient safeguards preventing arbitrary abuse. ${ }^{94}$

In the Gaskin judgment, it was determined that a fair balance between the interests of the individual versus those of the community, such as national security, must be struck. ${ }^{95}$ The delineation between cases with a terrorist element compared to those without can be scrutinized via the issue of security services granting access to information to individuals. The Court held that the barriers constructed by public authorities to the access of private information can lead to a violation of Article $8 \mathrm{ECHR},{ }^{96}$ as they have a duty to provide an effective procedure within a reasonable period of time regarding the retrieval of said information. On the other hand, when there is a suspicion of terrorism, the Court has deemed the interests of combating terrorism and national security to be of greater significance than the defendant's interest. ${ }^{97}$ Marginal discretion granted by the ECtHR allows for the domestic government to make a security assessment, thereby creating a legitimate basis for a proportionate infringement upon an individual's right to private life. The development of such case law can lead to misuse and overextension of the restriction of freedoms. Thus, the use of secret surveillance is governed by the proportionality test.

The ECtHR advocates that when an applicant claims to be the victim of an Article 8 infringement, the mere presence of secret surveillance can amount to a violation. ${ }^{98}$ Further, the Court has argued that legislation which enables a system of secret surveillance to be legitimate is a threat to society. ${ }^{99}$ Governments' margin of discretion is limited in so far as adequate safeguards against abuse must be guaranteed, and competences pertaining to secret surveillance may only be tolerated if strictly necessary for the protection of democratic institutions. ${ }^{100}$ The lack of procedural safeguards surrounding the use of surveillance methods amounts to a violation, ${ }^{101}$ and therefore an ex ante judicial authorization ought to be granted through a body independent of the executive. ${ }^{102}$ However, pursuant to the modernization of technologies that terrorists can utilize, governments ought to be allowed to employ state of the art technology, including mass

93 Klass and Others $v$ Germany App no 5029/71 (ECHR, 6 September 1978 ) para 41.

94 Steven Greer, Human Rights files no 15 The Exceptions to Articles 8 to 11 of the European Convention on Human Rights (Council of Europe Publishing 1997) 10-20.

95 Gaskin v The United Kingdom (1989) 12 EHHR 36 para 42.

96 Haralambie v Romania App no 21737/03 (ECHR, 27 October 2009) para 96.

97 Segerstedt-Wiberg and Others $v$ Sweden App no 62332/00 (ECHR, 6 June 2006) para 91.

98 Roman Zakharov v Russia App no 47143/06 (ECHR, 20 October 2006) paras 171-172.

99 Weber and Saravia $v$ Germany App no 54934/00 (ECHR, 29 June 2006) para 78.

100 Klass and Others $v$ Germany App no 5029/71 (ECHR, 6 September 1978 ) para 42; Szabó and Vissy v Hungary App no 37138/14 (ECHR, 6 June 2016) para 72-73.

101 Bykov v Russia App no 4378/02 (ECHR, 10 March 2009) para 81.

102 Roman Zakharov v Russia App no 47143/06 (ECHR, 20 October 2006) para 258; Szabó and Vissy v Hungary App no 37138/14 (ECHR, 6 June 2016) para 77. 
surveillance, to prevent terrorist atrocities. This notwithstanding, in times of severe emergency where no time may be wasted, authorities must still be subject to and held accountable through ex post facto judicial review, for the sake of preventing the misuse of invasive measures and enabling a judicial remedy as a safeguard. ${ }^{103}$ The ECtHR therefore prevents an Orwellian-type surveillance State from coming to be, by placing limits on the discretion that national security considerations gives States in their fight against terrorism. This is a vital position for the Court to take, as otherwise a snowball effect of using national security to infringe upon human rights could occur.

The legal basis, the Regulation of Investigatory Powers Act, permitted extensive surveillance in the UK and was deemed unlawful in the Big Brother case. ${ }^{104}$ Yet, the ECtHR did not render mass surveillance programmes disproportionate in a blanket fashion. The Court grants wide discretion to States when protecting national security, ${ }^{105}$ and does not require the safeguard of prior judicial authorization as quintessentially necessary for the sake of legality. ${ }^{106}$ Moreover, the technological advances that assist terrorists to remain under the radar have broadened the discretion granted to States, thus warranting mass surveillance to an extent. ${ }^{107}$ Hence, less burdensome measures, such as targeted interception, were not deemed adequately efficient in combating terror. ${ }^{108}$ Consequently, the Court established necessity and foreseeability safeguards, through limiting the duration of data interception, as well as taking necessary precautions to ensure that data remains confidential. This was achieved through creating clear procedures for data management to tackle the issues of lack of transparency and ambiguity surrounding data interception. ${ }^{109}$ Ultimately, the mass infringement of the privacy of the population was deemed necessary in a democratic society, due to the need for an information flow between States when combating the global threat of terrorism, thus normalizing information sharing. ${ }^{110}$ Sophisticated terrorist tactics result in the need for ingenuity, as regular criminal procedures are less efficient and cannot always keep pace with this evolving threat. Moreover, the deterring nature of ordinary criminal punishments is less potent with regard to terrorism, as terrorists are radical and uninfluenced by the threat of imprisonment. Optimally, States should use specific, safeguarded surveillance tactics for the specific purpose of countering terrorism. Any data retention not in line with the aim of combating terrorism must be held unlawful, as a huge triumph for terrorists is for traditional freedoms to be undermined. ${ }^{111}$

${ }^{103}$ Szabó and Vissy v Hungary App no 37138/14 (ECHR, 6 June 2016) para 86.

${ }^{104}$ Big Brother Watch and Others v The United Kingdom App nos 58170/13, 62322/14, 24960/15 (ECHR, 13 September 2018).

105 Weber and Saravia v Germany App no 54934/00 (ECHR, 29 June 2006) para 106.

106 Big Brother Watch and Others v The United Kingdom App nos 58170/13, 62322/14, 24960/15 (ECHR, 13 September 2018) para 314.

107 ibid para 384.

108 ibid para 357.

109 Theodore Christakis, 'A Fragmentation of EU/ECHR Law On Mass Surveillance: Initial Thoughts On The Big Brother Watch Judgment' (European Law Blog, 20 September 2018) <europeanlawblog.eu/2018/09/20/a-fragmentation-of-eu-echr-law-on-mass-surveillance-initialthoughts-on-the-big-brother-watch-judgment/> accessed 3 June 2019.

${ }^{110}$ Big Brother Watch and Others $v$ The United Kingdom App nos 58170/13, 62322/14, 24960/15 (ECHR, 13 September 2018) para 446.

111 Ilina Georgieva, 'The Right to Privacy under Fire - Foreign Surveillance under the NSA and the GCHQ and Its Compatibility with Art 17 ICCPR and Art 8 ECHR' (2015) 31(80) Utrecht Journal of International and European Law 104, 120-130. 
States use counter-terrorism measures such as mass surveillance to prevent terrorist recruitment, which triggers a conflict between safety and the fundamental value of privacy. The assessment made by the ECtHR is strongly influenced through the Member State declaring a state of emergency as, in the event of a state of emergency, additional leeway in the form of a margin of appreciation is granted to the State. ${ }^{112}$ The nature of surveillance being based on algorithms leads to selective profiling, which functions discriminately in practice, resulting in minority groups having a high chance of being singled out. Despite this contribution towards the incarceration of terrorists, large numbers of innocents are affected. ${ }^{113}$ The permittance of new powers infringes the rights of law-abiding internet users, resulting in a populace sleepwalking towards a surveillance society for the potential gain of safety, which is horrifyingly reminiscent of an Orwellian tale. Hence, the ECtHR, alongside the Court of Justice of the European Union (CJEU), has established standards surrounding data protection and law enforcement, requiring a specific legal basis for any collection, storage, analysis and disclosure of data for anti-terrorism purposes. Moreover, the basis must entail binding rules with limits on statutory powers, for instance through an exact description of the type of information recorded, as well as the precise groups of people against whom the measures of gathering and retention of information may be taken. ${ }^{114}$ Additionally, a transparent procedure for the authorization of surveillance measures is equally essential for them to be lawful. ${ }^{115}$ Due to the intrusive nature of surveillance measures, such as phone tapping, strict necessity and proportionality tests, combined with strong safeguards as mentioned above, are of fundamental importance. ${ }^{116}$

In the following chapter, the Member States' dialogue with the ECtHR regarding the prohibition of torture, an absolute right, will be analysed, in order to show that national security is a substantial interest even when the ECtHR appears to be stringent.

\section{To Torture or Keep the Nation Secure?}

The global fight against terrorism, regardless of its definition, is never-ending, even at a national level, due to sporadic attacks preventing it from becoming a passing phenomenon. Thus, the implications of declaring an emergency situation as a response to terrorism are different from those declared in an ordinary situation of warfare. Life-threatening scenarios invoke a positive obligation upon States to ensure the safety of their citizens through doing everything that can be reasonably expected of them in preventing a real and immediate risk of death. ${ }^{117}$ As a result thereof, the right to security has in a sense been codified by the ECtHR as a human right, perhaps considering that security as an absolute right would relieve the tension between national security and other rights. For example, rather than a court weighing national security against a fundamental freedom, it could consider the absolute right to security of numerous citizens, thus legitimately superseding other human rights. In addition, the Guidelines on Human Rights and the Fight against Terrorism reiterate that it is a duty of the State to protect its populace from potential terrorist attacks. ${ }^{118}$ Therefore, it naturally follows that the ECtHR grants leeway to Member States

\footnotetext{
${ }^{112}$ Ian Brown and Douwe Korff, 'Terrorism and the Proportionality of Internet Surveillance' (2009) 6(2) European Journal of Criminology 119, 120.

113 ibid 132.

${ }^{114}$ Rotaru v Romania App no 28341/95 (ECHR, 4 May 2000).

115 Brown and Korff (n 101) 129.

116 ibid 130.

117 Osman v UK ECHR 1998-VIII 3124.

${ }^{118}$ Council of Europe, Guidelines on Human Rights and The Fight Against Terrorism (Council of Europe Publishing 2012).
} 
in fulfilling this obligation. Nonetheless, the police must still exercise their competences in a way that respects due process and other Convention rights. ${ }^{119}$ Due to the State having the task of balancing these competing rights with one another, they often resort to the implementation of 'sunset clauses' during a state of emergency, which ordinarily would expire after a given time period and would have to be passed through parliament again. ${ }^{120}$ Due to the timeless nature of terrorism, states of emergency can last an extraordinarily long time, thus enabling allegedly temporary measures which are more intrusive than normally permitted to be established and codified into ordinary criminal law.

In Lawless $v$ Ireland, ${ }^{121}$ the ECtHR supported a state of emergency as an 'exceptional situation of crisis or emergency which affects the whole population and constitutes a threat to the organised life of the community of which the State is composed. ${ }^{122}$ Further, the Court deemed Ireland justified in utilizing the derogation, due to the violent and unconstitutional nature of the activities on its territory. ${ }^{123}$ Moreover, special anti-terrorism laws were justified due to the ordinary justice system being insufficient to restore peace and order, as evidence gathering methods were inadequate to achieve prosecutions. ${ }^{124}$ This is in accordance with the criteria later proposed through the Commission in The Greek Case. ${ }^{125}$ The Court controversially claimed jurisdiction in assessing whether an emergency truly threatens the life of a State, but subsequently employed a wide margin of appreciation when making such an assessment on the respective government's derogation. ${ }^{126}$ This is much to the appeasement of sovereign States who believe themselves to be in a better position to assess emergency situations than a court in Strasbourg, as it is their domaine reserve. ${ }^{127}$ Democratically elected national governments should possess responsibility for the lives of their citizens and should ideally be supervised by the ECtHR, which can assess whether a particular measure invoked under the derogation clause is proportionate. The Court assesses proportionality by considering the nature of the rights affected, whether they are absolute or fundamental, the severity of the restriction and the length of the emergency situation. ${ }^{128}$ For example, a lengthy ban on the fundamental right to assembly due to a state of emergency would be disproportionate due to the importance of the freedom of assembly to a democratic society, ${ }^{129}$ unless no alternate measures were available and the result would be disorder. ${ }^{130}$

119 Osman v UK ECHR 1998-VIII 3124.

${ }^{120}$ For instance, the Terrorism Act 2006 was subject to a 12 -month sunset provision meaning it had to be extended on a yearly basis.

${ }^{121}$ Lawless $v$ Ireland (1961) 1 EHRR 15.

122 ibid para 28.

123 ibid para 30.

124 ibid paras 36-37.

${ }^{125}$ The Greek Case App nos 3321/67, 3322/67, 3323/67, 3344/67 (ECHR, 1969); (1) It must be actual or imminent; (2) Its effects must involve the whole nation; (3) The continuance of the organized life of the community must be threatened; (4) The crisis or danger must be exceptional, in that the normal measures or restrictions permitted by the Convention for the maintenance of public safety, health and order, are plainly inadequate.

${ }^{126}$ Ireland v UK App no 5310/71 (ECHR, 13 December 1977) para 96.

${ }^{127}$ Natasa Mavronicola and Francesco Messineo, 'Relatively Absolute? The Undermining of Article 3 in Ahmad v UK' (2013) 76(3) The Modern Law Review 580, 585.

128 Julian Müller, 'European human rights protection in times of terrorism - the state of emergency and the emergency clause of the European Convention on Human Rights' (2018) 28(4) Zeitschrift fuer Politikwissenschaft 581, 587.

${ }^{129}$ Louise Doswald-Beck, Human Rights in Times of Conflict and Terrorism (Oxford University Press 2011) 425.

${ }^{130}$ Christians against Racism and Fascism $v$ the United Kingdom App no 8440/78 (ECHR, 16 July 1980). 
During times of emergency, a lower limit still exists, which States must not cross when combating terrorism even if the life of the nation is in jeopardy. Ireland $v U K$ was a landmark judgment, ${ }^{131}$ resulting in the ECtHR considering that five techniques amounted to a violation of Article $3 \mathrm{ECHR},{ }^{132}$ although they were not considered to be torture, but rather inhuman and degrading treatment. ${ }^{133}$ The Court created a delineation between degrading treatment and torture, thereby creating a potentially dangerous flexibility regarding the margin of appreciation granted to the UK under Article $15 \mathrm{ECHR},{ }^{134}$ which could potentially lead to allowing brutal methods which cannot quite be considered torture. Although a wide margin of appreciation is granted, power is not unlimited. ${ }^{135} \mathrm{On}$ the other hand, a precedent of cumulative mistreatment amounting to a breach of Article 3 ECHR was established. Yet, in Becciev v Moldova, ${ }^{136}$ a violation of Article 3 was not found due to mistreatment occurring in isolated instances.

The ECtHR has directly impacted counter-terrorism legislation through its precedents, but also indirectly in the UK. The Home Secretary had the power to label an individual as an international terrorist, ${ }^{137}$ thereby allowing the person to be deported or, if they would be subject to torture, to be incarcerated indefinitely. ${ }^{138}$ The derogation clause invoked by the UK hindered the ECtHR from taking action. ${ }^{139}$ This derogation was contested in Belmarsh detainees, ${ }^{140}$ where the applicants claimed unlawful discrimination on the ground of nationality, contrary to Article 14 ECHR in conjunction with Article 5 ECHR. The House of Lords quashed the UK's derogation order and announced that the indefinite detention of foreign terrorists was incompatible with the right to liberty and the parasitic right of the prohibition of discrimination. The majority of the Lords considered the emergency derogation to be legitimate, as the life of the nation had been threatened. Regardless, under the circumstances, the indefinite detention of, specifically, foreigners, was disproportionate and lacked justification. The Lords employed a proportionality test and concluded that alleged international terrorists were not any more of a risk than British ones who were not subject to such a draconian measure. ${ }^{141}$ Moreover, less burdensome measures to control the suspects would have been sufficient to neutralize the threat.

${ }^{131}$ Ireland v UK App no 5310/71 (ECHR, 13 December 1977).

132 (a) wall-standing: forcing the detainees to remain for periods of some hours in a 'stress position', described by those who underwent it as being 'spreadeagled against the wall, with their fingers put high above the head against the wall, the legs spread apart and the feet back, causing them to stand on their toes with the weight of the body mainly on the fingers'; (b) hooding: putting a black or navy-colored bag over the detainees' heads and, at least initially, keeping it there all the time except during interrogation; (c) subjection to noise: pending their interrogations, holding the detainees in a room where there was a continuous loud and hissing noise; (d) deprivation of sleep: pending their interrogations, depriving the detainees of sleep; (e) deprivation of food and drink: subjecting the detainees to a reduced diet during their stay at the centre and pending interrogations; Ireland $v$ UK App no 5310/71 (ECHR, 13 December 1977) para 96.

${ }^{133}$ Ireland v UK App no 5310/71 (ECHR, 13 December 1977) para 167; Babar Ahmad and Others $v$ The United Kingdom App nos 24027/07, 11949/08, 36742/08, 66911/09 ,67354/09 (ECHR, 10 April 2012) para 179.

${ }^{134}$ Mavronicola and Messineo (n 115) 598.

${ }^{135}$ Ireland v UK App no 5310/71 (ECHR, 13 December 1977) para 207.

136 Becciev v Moldova (2007) 45 EHRR 11.

137 Anti-terrorism, Crime and Security Act 2001.

138 ibid part 4 s 23 .

139 The ECtHR would have prevented this violation of Article 5 ECHR, deprivation of liberty, from happening if the UK government had not opted to derogate from the ECHR under Article 15.

${ }^{140} A$ and others $v$ Secretary of State for the Home Department [2004] UKHL 56, [2005] 2 WLR 87.

${ }^{141}$ For example, in the 7/7/2005 bombings in London, all offenders had British citizenship. 
Furthermore, the UK government hypocritically permitted the suspects to vacate the country to States where they did not face the threat of torture, despite the suspects allegedly posing an international terror threat. ${ }^{142}$ Conclusively, the mere existence of the ECtHR influences domestic British judges to respect human rights. Prior to the Belmarsh case, it had been unprecedented for UK judges to adjudicate on the legitimacy of measures adopted in good faith on national security grounds, thereby demonstrating that the judicial dialogues between the European and UK courts have led to a greater assurance of human rights. ${ }^{143}$

Unlike fundamental freedoms, an absolute right such as Article 3 ECHR has no provision for exceptions and, pursuant to Article 15(2) ECHR, cannot be deviated from, ${ }^{144}$ even under an emergency derogation and the most difficult circumstances, such as the fight against terrorism. ${ }^{145}$ The Gäfgen case ostensibly does not reaffirm prior precedents such as Saadi $v$ Italy, ${ }^{146}$ which deemed torture absolutely prohibited in all circumstances. The absolute prohibition of torture was non-negotiable, even in cases of extradition where there was a 'genuine risk' of torture, ${ }^{147}$ until the recent Ahmad $v$ UK case,${ }^{148}$ where the ECtHR seemingly undermined the non-refoulment principle. Despite rejecting the relativist notion of the UK House of Lords, ${ }^{149}$ which attempted to alleviate the responsibility of the extraditing State, the ECtHR left the status of Article 3 ambiguous with respect to extraditions. ${ }^{150}$ The Court permitted the extradition of numerous suspected terrorists to face prosecution in an extreme maximum-security detention center in the USA. ${ }^{151}$ The ECtHR deemed that a highly restrictive prison did not amount to a violation of Article 3, ${ }^{152}$ as an extensively long period of incarceration would not be considered incompatible with the aforementioned Article, but rather would be grossly disproportionate and therefore incompatible. ${ }^{153}$ The Court considered that ill-treatment must achieve a minimum standard of severity to trigger Article 3 ECHR through analyzing the particular context, ${ }^{154}$ duration, physical and mental effects of the punishment. ${ }^{155}$ As the Court's methodology is factsensitive, a degree of relativity regarding the absolute right still exists pragmatically, because defining inhuman and degrading treatment does involve a degree of subjectivity. The affected individual also plays an important role in the proportionality assessment of

142 Secretary of State for the Home Department v Rehman [2003] 1 AC 153 (HL).

143 David Feldman, 'Proportionality and Discrimination in Anti-Terrorism Legislation Case and Comment' (2005) 64(1) Cambridge Law Journal 271, 271-273.

144 Ireland $v$ UK App no 5310/71 (ECHR, 13 December 1977) para 163.

145 Gäfgen v Germany (2011) 52 EHRR 1 para 87.

146 Saadi v Italy (2009) 49 EHRR 30 para 82.

${ }^{147}$ Chahal v the United Kingdom App no 70/1995/576/662 (ECHR, 11 November 1996).

${ }^{148}$ Babar Ahmad and Others $v$ The United Kingdom App nos 24027/07, 11949/08, 36742/08, 66911/09, 67354/09 (ECHR, 10 April 2012) para 176.

${ }^{149} R$ (on the application of Wellington) (FC) $v$ Secretary of State for the Home Department (Criminal Appeal from Her Majesty's High Court of Justice) [2008] UKHL 72.

150 Babar Ahmad and Others v The United Kingdom App nos 24027/07, 11949/08, 36742/08, 66911/09, 67354/09 (ECHR, 10 April 2012) para 177.

${ }^{151}$ In para 177 the Court ruled: 'treatment which might violate Article 3 because of an act or omission of a Contracting State might not attain the minimum level of severity which is required for there to be a violation of Article 3 in an expulsion or extradition case.'.

152 Babar Ahmad and Others $v$ The United Kingdom App nos 24027/07, 11949/08, 36742/08, 66911/09, 67354/09 (ECHR, 10 April 2012) paras 218-224.

153 ibid para 242.

154 Ireland v UK App no 5310/71 (ECHR, 13 December 1977) para 65.

155 Soering $v$ UK (1989) 11 EHRR 439 para 90. 
whether a punishment constitutes a violation of Article $3 .{ }^{156}$ For instance, in the $D D$ case, ${ }^{157}$ the British court took the applicant's mental state due to PTSD into account when assessing whether a TPIM, ${ }^{158}$ entailing numerous movement restrictions, equaled torture. Nevertheless, the Court reasoned that in order to determine whether something is torture, one must assess the impact of the measure on the individual against the measure's proportionality pursuant to national security. ${ }^{159}$ As the effects of the TPIM did not pass the threshold of Article 3, no violation was found. Yet, the fact that the applicant was mentally ill played a role in reducing some of the restrictions imposed on him. ${ }^{160}$

Ultimately, the ECtHR's ruling is worrisome, ${ }^{161}$ as a right being absolute ought to mean that no exceptions are permitted, and universal application is enforced. Besides this, the Court claimed in its reasoning for permitting the extradition that a real risk would rarely be found in countries with historic democratic values, hence a dichotomy between trustworthy countries and non-trustworthy countries was implied, despite the USA being predisposed to the use of torture. ${ }^{162}$ Lastly, the preventative scope of Article 3 was impaired, as in cases of expulsion one can only know after the event whether torture occurred, thus rendering the absolute right less effective. ${ }^{163}$

\section{Conclusion}

This paper has analyzed the extent to which terrorist threats limit the enjoyment of individual liberties. Conclusively, the ECtHR appreciates the necessity of a special system of anti-terrorism laws due to the significance of national security. Consequently, discretion is granted to Member States when defending themselves against terrorist threats, which is nonetheless limited through the proportionality assessment. Proportionality functions as a strategy that ensures Member States utilize sufficient safeguards when imposing restrictive legislation, through demanding specifically targeted and transparent laws.

Terrorism is treated differently to ordinary crimes, as governments declare emergency situations. Hence, national security becomes of paramount importance in contrast to other rights. This is evident when comparing jurisprudence on human rights infringements associated with terrorist measures, which are drafted in the name of national security, with ordinary interferences. Moreover, the derogation clause's interplay with relative and absolute rights permits additional leeway via the margin of appreciation.

Surveillance and stop-and-search are archetypical anti-terrorism measures limited by the ECtHR in order to not excessively infringe upon human rights, thereby being in accordance with Lloyd's notion of imposing sufficient safeguards if new measures are enacted.

Although the ECtHR can be considered an essential guarantor for human rights through its judicial dialogues and influences on domestic courts and governments, the issue of refoulment in torture cases must be readdressed in upcoming case law. Moreover, the extent to which grave privacy infringements are permitted is terrifying, as the longer the ECtHR takes to take a solid stance against States abusing the aim of national security, the

\footnotetext{
${ }^{156}$ Mavronicola and Messineo (n 115) 593.

${ }^{157}$ DD v Secretary of State for Home Department [2014] EWHC 3820 (Admin).

158 Terrorism and Prevention and Investigation Measure in the form of an ankle brace.

${ }^{159}$ DD v Secretary of State for Home Department [2014] EWHC 3820 (Admin) [126].

${ }^{160}$ ibid [136].

${ }^{161}$ Babar Ahmad and Others $v$ The United Kingdom App nos 24027/07, 11949/08, 36742/08, 66911/09, 67354/09 (ECHR, 10 April 2012) para 177.

162 ibid para 179.

${ }^{163}$ Mavronicola and Messineo (n 115) 600-602.
} 
more severe it will naturally become due to society's incremental progression towards a digital life.

Ultimately, terrorism tests democratic governments uniquely, as imposing draconian measures would be an easy way to ensure the safety of the population. Nonetheless, fighting with one hand behind one's back is necessary to uphold the status of a rights-respecting democracy. Only time will tell whether the ECtHR will evolve to hand down proactive verdicts to ensure human rights are protected prior to their breach. 